\title{
Organic management of dietary rosemary extract in dairy sheep: effects on milk quality and clotting properties
}

\author{
B. Chiofalo • E. B. Riolo • G. Fasciana • L. Liotta • \\ V. Chiofalo
}

Published online: 1 May 2010

(C) Springer Science+Business Media B.V. 2010

\begin{abstract}
The increasing demand for animals from organic breeding systems has increased interest in certain natural substances, called nutraceuticals, to stimulate the organic defenses of the animals. The aim of this trial was to study the effects of dietary rosemary extract in 36 ewes, from 57 to 154 days of lactation, divided into three groups: CTR (basal diet), ROXLD (600 mg extract/head/day) and ROXHD (1,200 mg extract/head/day). A significantly higher quantity of milk and quantitative daily production of protein, casein, fat, and lactose were observed in the milk of animals in the ROXHD group compared with milk from animals in the CTR and ROXLD groups. No significant differences were observed for somatic cell counts, considering that treated groups showed lower values compared with controls. A significant decrease in clotting time $(r)$ and increase in curd firmness $\left(a_{30}\right)$ were observed in milk of both treated groups (ROXLD and ROXHD) compared with the CTR group. These results could be related to the significantly higher acidity values, $\mathrm{pH}$ and $\mathrm{SH}^{\circ}$, observed in the milk of animals from the treated groups. Dietary rosemary extract in dairy sheep enhanced milk yield, quality, and renneting properties due to its "natural, functional ingredients."
\end{abstract}

Keywords Rosemary extract $\cdot$ Ewes $\cdot$ Milk

$\begin{array}{ll}\text { Abbreviations } \\ \text { BCS } & \text { Body Condition Score } \\ \text { DM } & \text { Dry Matter } \\ \text { CP } & \text { Crude Protein } \\ \text { EE } & \text { Ether Extract } \\ \text { CF } & \text { Crude Fibre } \\ \text { ANOVA } & \text { Analysis of Variance }\end{array}$

B. Chiofalo $(\triangle) \cdot$ E. B. Riolo $\cdot$ L. Liotta $\cdot$ V. Chiofalo

Dipartimento di Morfologia, Biochimica, Fisiologia e Produzioni Animali - Sezione di Zootecnica

e Nutrizione animale - Facoltà di Medicina Veterinaria, Polo Universitario dell'Annunziata,

98168 Messina, Italy

e-mail: biagina.chiofalo@unime.it

G. Fasciana

C.da Zotta Caldaia, Villarosa - Enna, Italy 


\section{Introduction}

The increasing demand for organically bred animals has increased interest in nutraceuticals, which are able to stimulate the natural defences of the animals (Savoini et al. 2003). Natural polyphenols found in leaves of Rosmarinus officinalis L. have potential therapeutic benefits because of their potent antioxidant activities and their anticancer and antiviral properties (Aruoma et al. 1996; Offord et al. 1997). The primary active components in rosemary extract are carnosol, carnosic acid, rosmarinic acid, rosmanol, and caffeic acid (Al-Sereitia et al. 1999); these compounds are considered "natural functional ingredients" (O'Connel and Fox 2001). Considering the scarce information on the use of rosemary extract in small ruminants as well as the fact that sheep breeding is one of the main forms of livestock farming in Sicily, the aim of the trial was to study, during lactation, the effects of dietary rosemary extract on milk yield, quality, and clotting properties in organically bred Valle del Belice dairy ewes.

\section{Materials and methods}

Research was carried out on 36 organically bred Valle del Belice ewes. Animals near parturition were divided into three groups of 12, homogeneous for number (12), age (2.5 years), parity (pluriparous), body condition score (BCS; 2.38), and milk production, referring to the previous lactation $(1,144 \mathrm{~g} /$ day $)$, raised in multiple boxes $\left(25 \mathrm{~m}^{2} /\right.$ group), provided with external paddocks (40 $\mathrm{m}^{2} /$ group), and fed with vetch-oat hay ad libitum (DM 91.15\%; CP 10.1\%; EE 1.3\%; CF 30.4\%; Ash 8.6\%, on a DM basis) and pellet concentrate (DM 87.50\%; CP 21.7\%; EE 3.4\%; CF 9.1\%; Ash 9.7\%, on a DM basis). Groups were referred to as: CTR that received the concentrate with no additions, ROXLD that received the concentrate with $600 \mathrm{mg} / \mathrm{head} /$ day of rosemary extract, and ROXHD that received the concentrate with $1,200 \mathrm{mg} / \mathrm{head} /$ day of rosemary extract. Dietary treatment began at parturition (Day 0) following the scheme reported in Table 1. Every 14 days from 57 to 154 days of lactation, the three experimental groups were subjected to eight controls. Individual milk yield was recorded as were the fat, protein, casein, lactose, and somatic cell count values on the individual milk samples (CombiFoss 6000, Foss Electric, Denmark). Moreover, pH (Orion EA 940), titration acidity (Soxhlet Henkel/100 mL), and clotting properties, according to the $r$ (clotting time), $k_{20}$ (curd firming time), and $a_{30}$ (curd firmness) parameters, were studied using a Formagraph instrument (Foss Electric) (ASPA 1995). Data were subjected to analysis of variance (SAS, 2001) using a two-factor model (treatment and data of sampling).

Table 1 Quantity of concentrate administered to the animals (g/head/day)

\begin{tabular}{llllll}
\hline Days & CTR & ROXLD & & ROXHD & \\
\hline & Basal diet & Basal diet & ROXP $^{\mathrm{a}}$ & Basal diet & ROXP $^{\mathrm{a}}$ \\
$0-10$ & 400 & 200 & 200 & - & 400 \\
$11-48$ & 600 & 400 & 200 & 200 & 400 \\
$49-154$ & 700 & 500 & 200 & 300 & 400 \\
\hline
\end{tabular}

${ }^{a}$ The ROXP concentrate was integrated with $0.3 \%$ of $\mathrm{ROXP}^{\circledR}$ (Rosmarinus officinalis $7.5 \%$; SEVECOM SpA, Italy) 
Table 2 Yield and composition of the milk for feeding (mean $\pm \mathrm{SE}, P$ )

\begin{tabular}{lccc}
\hline & CTR & ROXLD & ROXHD \\
\hline Total milk yield (g per day) & $575 \pm 18 \mathrm{a}$ & $531 \pm 19 \mathrm{aA}$ & $632 \pm 19 \mathrm{bB}$ \\
Protein (\%) & $5.84 \pm 0.05 \mathrm{a}$ & $5.86 \pm 0.05 \mathrm{a}$ & $5.68 \pm 0.05 \mathrm{~b}$ \\
Protein (g per day) & $32.69 \pm 0.92 \mathrm{AB}$ & $30.94 \pm 0.96 \mathrm{~A}$ & $35.11 \pm 0.97 \mathrm{~B}$ \\
Casein (\%) & $4.50 \pm 0.04$ & $4.51 \pm 0.04$ & $4.42 \pm 0.04$ \\
Casein (g per day) & $25.21 \pm 0.71 \mathrm{a}$ & $23.79 \pm 0.74 \mathrm{~A}$ & $27.27 \pm 0.75 \mathrm{bB}$ \\
Fat $\%$ ) & $7.67 \pm 0.10 \mathrm{~A}$ & $7.15 \pm 0.11 \mathrm{~B}$ & $7.71 \pm 0.11 \mathrm{~A}$ \\
Fat (g per day) & $43.37 \pm 1.29 \mathrm{aA}$ & $37.52 \pm 1.35 \mathrm{~B}$ & $47.47 \pm 1.36 \mathrm{bA}$ \\
Lactose (\%) & $4.38 \pm 0.03 \mathrm{~A}$ & $4.53 \pm 0.03 \mathrm{~B}$ & $4.58 \pm 0.03 \mathrm{~B}$ \\
Lactose (g per day) & $25.31 \pm 0.85 \mathrm{~A}$ & $24.12 \pm 0.89 \mathrm{~A}$ & $29.13 \pm 0.90 \mathrm{~B}$ \\
Solids non-fat $(\%)$ & $10.96 \pm 0.06$ & $11.07 \pm 0.06$ & $10.98 \pm 0.06$ \\
Total solids (\%) & $18.26 \pm 0.13 \mathrm{a}$ & $17.87 \pm 0.14 \mathrm{~b}$ & $18.30 \pm 0.14 \mathrm{a}$ \\
Somatic cell count $\left(10^{3} / \mathrm{mL}\right)$ & $292 \pm 40$ & $241 \pm 41$ & $227 \pm 41$ \\
\hline
\end{tabular}

Mean values with different capital and small and letters in the row are significantly different for $P<0.01$ and $P<0.05$, respectively

\section{Results}

Data for the yield and qualitative characteristics of the milk in relation to the feeding treatments are reported in Table 2. The ROXHD group yielded a significant higher quantity of the milk than the CTR and ROXLD groups. No significant differences were observed for somatic cell counts; however, the treated groups (ROXLD and ROXHD) showed slightly lower values than the control group. Supplementation of rosemary extract significantly increased the daily production of fat, protein, casein, and lactose content in the milk of the ROXHD group compared with the CTR and ROXLD groups. Nevertheless, the percentages of the qualitative parameters in relation to feeding did not show the same trend (Table 2) possibly due to an effect of dilution from the different production processes of milk recorded among the groups. Clotting parameters in relation to feeding are reported in Table 3. A significant decrease in clotting time $(r)$ and increase in curd firmness $\left(a_{30}\right)$ were observed in the milk of both treated groups (ROXLD and ROXHD) compared with the CTR group. The results could be related to the significant higher acidity values, $\mathrm{pH}$, and $\mathrm{SH}^{\circ}$ observed in the milk of the treated groups (Table 3).

Table 3 Clotting parameters of the milk for the feeding thesis (mean $\pm \mathrm{SE}, P$ )

\begin{tabular}{lccc}
\hline & CTR & ROXLD & ROXHD \\
\hline $\mathrm{pH}$ & $6.57 \pm 0.01 \mathrm{a}$ & $6.52 \pm 0.01 \mathrm{~b}$ & $6.53 \pm 0.01 \mathrm{~b}$ \\
Titration acidity $\left({ }^{\circ} \mathrm{SH} / 100 \mathrm{~mL}\right)$ & $10.29 \pm 0.13 \mathrm{~A}$ & $10.87 \pm 0.14 \mathrm{~B}$ & $10.84 \pm 0.14 \mathrm{~B}$ \\
Clotting time $-r(\mathrm{~min})$ & $20.47 \pm 0.45 \mathrm{aA}$ & $18.47 \pm 0.46 \mathrm{~B}$ & $18.98 \pm 0.45 \mathrm{bB}$ \\
Curd firming time $-k_{20}(\mathrm{~min})$ & $1.38 \pm 0.03$ & $1.35 \pm 0.03$ & $1.38 \pm 0.03$ \\
Curd firmness $-\mathrm{a}_{30}(\mathrm{~mm})$ & $51.59 \pm 1.43 \mathrm{~A}$ & $57.07 \pm 1.46 \mathrm{~B}$ & $56.89 \pm 1.44 \mathrm{~B}$ \\
\hline
\end{tabular}

Mean values with different capital and small and letters in the row are significantly different for $P<0.01$ and $P<0.05$, respectively 


\section{Discussion}

Results are within the ranges proposed for ewes of the Valle del Belice breed (Todaro and Scatassa 2001). Analysis of the somatic cells confirmed the good sanitary condition of the udders (Todaro and Scatassa 2001). The higher values of milk yield, protein, casein, fat, and lactose recorded in the ROXHD group could be related to the phenolic compounds found in rosemary leaves that could potentially have the following effects: i) improve the fermentative processes of the rumen, creating a strictly anaerobic environment; ii) interact in the reticulorumen with proteins, inhibiting their utilization in the rumen by indigenous microorganisms and allowing their availability in the abomasum (O'Connel and Fox 2001); iii) control the intestinal microflora; and iv) be resistant to fermentation in the rumen, allowing for their "potential availability" for absorption into the intestine (O'Grady et al. 2006). These properties of polyphenols could provide a better metabolic status of the animals (O'Connel and Fox 2001). Moreover, the higher milk yield recorded in the ROXHD group agrees with the observations of Sgoifo Rossi et al. (2005) in dairy cows receiving plant extracts with immune-stimulating effects (Ai-Hsiang et al. 2002). The higher acidity of the milk in treated groups improved the clotting properties, as shown by the higher clotting times and curd firmness in studies on ewes (Bianchi et al. 2004). Nevertheless, the qualitative parameters of the treated groups did not always show the same trend of rosemary extract supplementation, which could be related to a "dose-response effect" as reported by Savoini et al. (2003) in dairy goats that received two different doses of rosemary extract. Thanks to its "natural functional ingredients," $R$. officinalis L. can enhance the zootechnical parameters of significant technical and economic interest, including milk-clotting properties, since ewe's milk is entirely employed in cheese making.

Acknowledgements This work was supported by grants from the Institute of Experimental Husbandry of Sicilian Region, Palermo, Italy. The authors want to thank the Dept. S.En.Fi.Mi.Zo., University of Palermo, Italy and the Feed Industry SEVECOM SpA, Milan, Italy.

\section{References}

Ai-Hsiang L, Yu-Chih L, Shoei-Yn LS, Chi-Tang H, Jen-Kun L (2002) Carnosol, an antioxidant in rosemary, suppresses inducible nitric oxide synthase through down-regulating nuclear factor- $\mathrm{KB}$ in mouse macrophages. Carcinogenesis 23:983-991

Al-Sereitia MR, Abu-Amerb KM, Sena P (1999) Pharmacology of rosemary (Rosmarinus officinalis L.) and its therapeutic potentials. Indian J Exp Biol 37:124-131

Aruoma OI, Spencer JP, Rossi R, Aeschbach R, Kahn A, Mahmood N, Munoz A, Murcia A, Butler J, Halliwell B (1996) An evaluation of the antioxidant antiviral action of extracts of Rosemary and provençal herbs. Food Chem Toxicol 34:449-456

Associazione Scientifica di Produzione Animale (1995) Metodi di analisi del latte delle principali specie di interesse zootecnico. Università degli Studi di Perugia

Bianchi L, Bolla A, Budelli E, Caroli A, Casoli C, Pauselli M, Duranti E (2004) Effect of udder health status and lactation phase on the characteristics of Sardinian ewe milk. J Dairy Sci 87:2401-2408

O'Connel JE, Fox PF (2001) Significance and applications of the phenolic compounds in the production and quality of milk and dairy products: A review. Int Dairy J 11:103-120

Offord EA, Mace K, Avanti O, Pfeifer AM (1997) Mechanisms involved in the chemoprotective effects of rosemary extract studied in human liver and bronchial cells. Cancer Lett 114: 275-281

O’Grady MN, Maher M, Troy DJ, Moloney AP, Kerry JP (2006) Dietary supplementation and addition of tea catechins: Assessment of the effects of catechin level and $\mathrm{pH}$ on antioxidant activity in fresh beef. Proceedings of the $52^{\text {nd }}$ International Congress of Meat Science and Technology, Dublin, Ireland, pp 735-736 
SAS/STAT (2001) User's Guide, Version 8.2. SAS Institute Inc, Cary, NC

Savoini G, Cattaneo D, Paratte R, Varisco G, Bronzo V, Moroni P, Pisoni G (2003) Dietary rosemary extract in dairy goats organically managed: effects on immune response, mammary infections and milk quality. Ital J Anim Sci 2 (Suppl. 1):548-550

Sgoifo Rossi CA, Dell'Orto V, Peri V, Pinotti L (2005) Impiego di prodotti omeopatici e fitoderivati nell'allevamento della bovina da latte. AGRIOK Newsl 32:1-4

Todaro M, Scatassa ML (2001) La qualità del latte nella razza ovina "Valle del Belice". Tipografia Ausonia, Palermo 